UDC 622.22.553.4:519.85 https://doi.org/10.37101/ftpgp23.01.015

\title{
ORGANIZATION OF PRODUCTION ACTIVITIES OF A REGIONAL COAL-MINING COMPLEX
}

\author{
O.M. Ashcheulova ${ }^{1 *}$, L.Ya. Fomichova ${ }^{1}$, O.R. Mamaikin ${ }^{1}$, V.M. Pochepov ${ }^{1}$, \\ V.V. Lapko ${ }^{1}$ \\ ${ }^{1}$ Dnipro University of Technology, Dnipro, Ukraine \\ *Corresponding author: e-mail: alex.mamaikin80@gmail.com
}

\begin{abstract}
Objective is to propose a new approach to investment allocation in the group of coal-mining enterprises.

Methods. To solve the specified objective, a complex approach has been applied including assessment of enterprise investment attractiveness, determination of production potential, and definition of the possibility to switch to a break-even mode. The process of planning the ways to save industrial potential of coal-mining regions may be considered as the representation of multidimensional space (initial and design values) in terms of the one-dimensional (amount of investment money) one.
\end{abstract}

Findings. It has been established that the stage dealing with the development of a model for managing processes for mine unprofitability reduction should involve consideration of 8-10 factorial features, which may determine the formation of economic potential, taking into account peculiarities of the remaining deposits and their quality, as the integral assessment of mine potential in terms of both state and non-state investments. The formulated objective means selection of the minimum number of factors, which would reflect in the most adequate way the internal potential of a mine expressed by economic added value - as a consequence of interaction of factors of coal mine economic activities in specific mining, geological, and technological conditions.

Originality of the research is in the fact that it is expedient to use an indicator of economic reliability, which synthesizes the capacity of links, economic level of technical and economic indicators, and the amount of remaining deposits, as a complex component of the level of an unprofitable mine. The mentioned indicators determine the residual life of the mine. Their physical content is not identical; and it is the fact that helps (in terms of their joint use) obtain more complete estimate than when using any single indicator.

Practical implications. Practical significance includes actual assessment of the state of Donbas coal enterprises and determination of marginal break-even indicators, which has made it possible to elaborate recommendations for attracting financial resources. 
Keywords: coal mines, coal-mining region, break-even, modelling, diversification, potential, reserves

\section{INTRODUCTION}

Military actions in western regions of the country effect considerably the level of costs for renewal of Donbas in general and coal field in particular. The government assesses the losses to be several billion hryvnas; moreover, the level of destruction is experiencing its constant growth. The European Union is going to send a special mission for stocktaking and cost estimation with the following possible aid rendering. It is obvious that the overall plans of Western Ukraine recovery should include certain measures aimed at coal field revival [1, 2, 3]. That revival of Donbas enterprises and, first of all, coal industry means solution of certain social problems, which are stipulated by the following:

- considerable share of social costs in the overall amount of costs for renewal of state mines damaged by the war;

- great difference between actual financing and the industry needs as for the support of each ton of production capacity; and

- negative effect of previous restructuring upon a social-economic situation of the mining mono-production towns, being shown in terms of growing unemployment, reduced industrial production, and low level of population income in those towns.

Nowadays, Ukraine has 450 town; 344 of them belong to the category of small ones: their population of less than 50 thous. people. Generally, about $6.5 \mathrm{mln}$ people are living there, accounting for $13.5 \%$ of the whole population of the country. Only $7 \%$ of small towns can characterize their life as more or less comfortable. The rest belongs to so-called depressive ones as they belong to the category of monofunctional settlements, which life is supported by one or two functioning enterprises. Talking about some specific things, main problems being faced by the citizens of Shakhtarsk, Dzerzhynsk, Ukrayinsk, Torez, Snizhne and many others are as follows: low income (50.3\% of the respondents) and unemployment [4].

As before, unemployment is still one of the main unsolved problems in Donbas. If it could be solved, many other problems might be eliminated. Thus, while answering the question about the things, which the towns lack to improve living conditions of their citizens, the majority of respondents $(48.6 \%)$ say that they lack financial resources for social support as well as investment in the town economy $(22 \%)$. Currently, depressive territories include settlements where coal-mining and coal-processing enterprises have been experiencing their liquidation since 1996. The town of Snizhne is a bright example of such territory in Donetsk Region where seven mines were operating at the rise of Independence. Today, only one mine is operating there with the unemployment reaching up to $75 \%$. The same situation can be observed in the town of Torez where only three mines are operating among the 13 ones; even those three mines have stopped their activity after being damaged due to military actions [5].

In this regard, state support of coal-mining Donbas regions, where the majority of population is involved in coal mine operation, will be reduced to reaching complete employment for the residents. In this context, due to lack of budgetary 
funds, it is directed investment that is required most of all $[6,7]$, i.e. selection of a corresponding region, evaluation of its degree of negligence as well as prospects of its mines $[8,9]$ from the viewpoint of their coal reserves quality [10].

Papers by O.I. Amosha [11], V.G. Griniov [12], D.Yu. Cherevatskyi [13], P.V. Cherepovskyi [14], A.O. Khorolskyi [15] deal with innovative aspects of Ukrainian economy in general and fuel and energy complex in particular. Papers $[12,14]$ deal with the development of practical recommendations as for substantiation of rational level of production for unprofitable mines of Central region of Donbas; those studies also identify the degree of intensity of use for the fixed capacities. Besides, the represented approaches make it possible not only to develop recommendations but also to make long-term forecast. Thus, to stabilize the industry state, it is necessary to carry out analyses of the balance of labour resources, attracted capital, and end level of mining - such use of the available common world-economy criteria will help solve the problems of effective development of mineral deposits. The logics of those assumptions is explained by the available area of rational projecting [12], i.e. irrespective of mining and geological conditions of the deposit and current technical and economic factors, there is always a set of parameters making it possible to enter a break-even levelthat is, to select a rational living format [15].

As for foreign studies analyzing a problem of innovative prospects of the development of coal deposits, they are as follows: Nieć M. [16], C. Cyrnek [17], M. Krzak [18], B. Balusa [19], P. Li [20], and M. Beaulieu [21]. In particular, paper [16] highlights that increase in the production efficiency requires balanced flows of input and output resources depending on the production scenario. The authors of [22] use a retrospective analysis to assume that currently it is impossible to overcome the crisis in the industry without investment attraction. Moreover, further delay will result in stagnation and transit from "stable decay" to uncontrolled closure of production facilities. Thus, it is necessary to develop certain mechanisms of the evaluation of expediency of support for coal mines [23].

\section{STATEMENT OF THE PROBLEM}

Objective of the research is generalization and development of scientific and methodological basis, elaboration of a toolset and algorithm for modelling interinfluence of the level of population living in coal-mining regions and operation stability of mines and thermal power stations. To renew infrastructure in coalmining regions, it is necessary to develop scientific basis to support stabilization and augment industrial potential by forming stable connections between mines and related enterprises. That requires the following:

- description of the relation between mines, processing plants, electric power stations - incidence matrix can be applied for this purpose; and

- division of the totality of relations into certain hierarchies, i.e. substitution of positive feedback (the greater the output is, the more electric energy is required) with two negative successive ones (the more coal the mine extracts, the less its unused capacity is; and the less the unused mine capacity is, the more electric energy it requires) - i.e. application of a decomposition method. 


\section{RESEARCH METHODS}

Assume that a group of interrelated enterprises is characterized by certain volume of commercial coal products, and those products can be manufactured only in terms of certain number of enterprises. It is known that the loss norms per product unit vary depending on its production volume. However, in case of unprofitable coal enterprises equipped with unreliable cleaning facilities, production losses in terms of adopted technology and intensity most commonly do not experience visible changes depending on the fact, which machine complexes and which number of those complexes are involved in coal mining [24]. Qualitative evaluation of the conditions of certain technological links determining the production capacity of a mine is the indispensible conditions to identify different trends in coal-mining efficiency increase and capacity growth. The evaluation may be performed with the help of totality of the mentioned parameters; in this regard, specific parameters can be calculated either per unit of the extracted reserves or per unit of the annual volume of coal extraction. Here, the following ratio is true:

$$
\begin{gathered}
P_{j z}=\frac{\sum_{t} P_{j z}}{Z}=\frac{\sum_{t} P_{j D_{t}} D_{t}}{\sum D_{t}}, \\
P_{j D t}=\frac{P_{j t}}{D_{t}},
\end{gathered}
$$

where $P_{j z}$ is $j^{\text {th }}$ specific parameter in the calculation per unit of reserves; $P_{j t}$ is $j^{\text {th }}$ absolute parameter during $t^{\text {th }}$ year of mine operation; $Z$ is reserves being extracted per whole period of the mine (level) operation; $P_{j D t}$ is $j^{\text {th }}$ specific parameter as calculated per extraction unit during $t^{\text {th }}$ year; $D_{t}$ is volume of coal extraction of a mine (level) during $t^{\text {th }}$ year.

At the same time, to eliminate the most possible number of intermediate production stages from the consideration, it is convenient to express costs of labour items entering an enterprise from outside, and costs of primary resources by means of linear function of end ("product") output of that enterprise. To do that, apart from the linear dependence of costs on the output (processing) volume during all stages, it is required that the enterprise does not get any products, which it can manufacture by itself, from outside [24]. Thus, it is expedient to introduce a concept of production unit along with the concept of enterprise into the conditions of model development. The concept of production unit is understood as a group of production sites, for which the following conditions may be considered as the feasible ones:

1) if a production unit can manufacture products of the specific type, then it does not get it from outside; and

2) technological norms of costs per production unit of the specific type do not experience any changes depending on the changes in production volume or distribution of that product throughout the production unit equipment. According to that definition, an enterprise, at which, for instance, any further stage of production can be provided with raw materials from the previous stage only 
partially, and the shortage is covered by supplies from outside, cannot be considered as a production unit, but it is considered as their totality.

Such a definition of a production unit demonstrates one of the differences of statement of real problem from the internal production tasks of linear programming for the best equipment use. If that concept was not introduced, the proposed tasks would transform into a problem of specialization for certain mines or sites of mine fields of a concrete group of enterprises. Volumes of products of $i^{\text {th }}$ type manufactured for the supply to other national regions are the unknowns of that problem related immediately to certain production units.

\section{RESEARCH RESULTS}

In the context of the situation of renewal of social stability and potential of coalmining Donbas regions ruined by the war, a multistage distribution problem should be considered. The essence of the problem is as follows: it is required to renew enterprises considered as sources of energy carriers and as electric energy consumers by the end of a planned period within the spatially separated points of a certain region. Possible variants of the mine potential renewal are known as well as their maximum possible capacity.

Introduce the following designations: $X_{l i}^{2 j}$ is volume of coal supplies of $i^{\text {th }}$ mine to $j^{\text {th }}$ electric power station; $X_{2 j}{ }^{s}$ is output of electric energy from $j^{\text {th }}$ electric power station to $s^{\text {th }}$ consumer; $X_{2 j}^{l i}$ is unused capacity of $l_{i}^{\text {th }}$ mine; $f_{l}$ is costs for production of 1 thous. $\mathrm{t}$ of coal in terms of $i^{\text {th }}$ mine; $f_{2}$ is costs for production of $1 \mathrm{mln}$ of $\mathrm{kW}-\mathrm{h}$ of electric energy of $j^{\text {th }}$ electric power station; $u_{i}$ is costs for transportation of $1 \mathrm{t}$ of coal from $i^{\text {th }}$ mine to $j^{\text {th }}$ electric power station; $\lambda_{i}$ is costs of electric energy and costs for its transmission from $j^{\text {th }}$ electric power station to $s^{\text {th }}$ consumer; $M_{i}, M j, M_{2 i}$ are maximum possible capacity of mines, electric power stations, and processing plants respectively; $D s$ is demand of $s^{\text {th }}$ consumer; $\gamma_{i}$ is need of $i^{\text {th }}$ mine in electric energy; $l_{1 i}, l_{2 i}$ are labour productivity in terms of $i^{\text {th }}$ mine and processing plant respectively; $L_{R}$ is amount of employable population of the region.

The problem is described by the following system of correlations.

To minimize in terms of the following:

$$
\begin{gathered}
F=\sum_{i=1}^{n_{1}} \sum_{j=1}^{n_{2}}\left[f^{1 i}+u_{1 i}{ }^{2 j}+\lambda_{1 i}{ }^{2 j}\right] X_{1 i}{ }^{2 j}+\sum_{j=1}^{n_{2}} \sum_{s=1}^{n_{3}} u_{2 j}{ }^{s}+\sum_{j=1}^{n_{2}} \sum_{i=1}^{n_{1}} u_{2 j}{ }^{1 i} X_{2 j}{ }^{1 i}=\min \\
\sum_{j=1}^{n_{2}} X_{1 i}{ }^{2 j}+X_{1 i}=M_{1 i} \sum_{i=1}^{n_{1}} \lambda_{1 i}{ }^{2 j} X_{1 i}{ }^{2 j}+X_{2 j}=M_{2 j} \\
\sum_{s=1}^{n_{3}} X_{2 j}{ }^{s}+\sum_{i=1}^{n_{1}} X_{2 j}{ }^{1 i}+X_{2 j}=M_{2 j} \\
\sum_{j=1}^{n_{2}} \lambda_{2 j}{ }^{s} X_{2 j}{ }^{s}=D_{s}
\end{gathered}
$$




$$
\begin{aligned}
& \sum_{j=1}^{n_{2}} \lambda_{2 j}{ }^{s} X_{2 j}{ }^{s}=D_{s} \\
& \sum_{j=1}^{n_{2}} \lambda_{2 j}{ }^{1 i} X_{2 j}{ }^{1 i}=\gamma_{i} \sum_{j=1}^{n_{2}} X_{1 i}{ }^{2 j}, \\
& \sum_{i=1}^{n_{1}} \frac{M_{1 i}}{l_{1 i}}+\sum_{i=1}^{n_{2}} \frac{M_{2 i}}{l_{2 i}} \leq L_{R}
\end{aligned}
$$

A matrix (Fig. 1) built on the basis of a model (1) - (7) makes it possible to formulate a series of important principles of stabilization of a situation within a specific region. The essence of those principles is in the substitution of positive feedback (the more coal the mine extracts, the more energy it needs) with two negative successive relations (the more coal the mine extracts, the less its unused capacity is; and the less the unused mine capacity is, the more electric energy it requires).

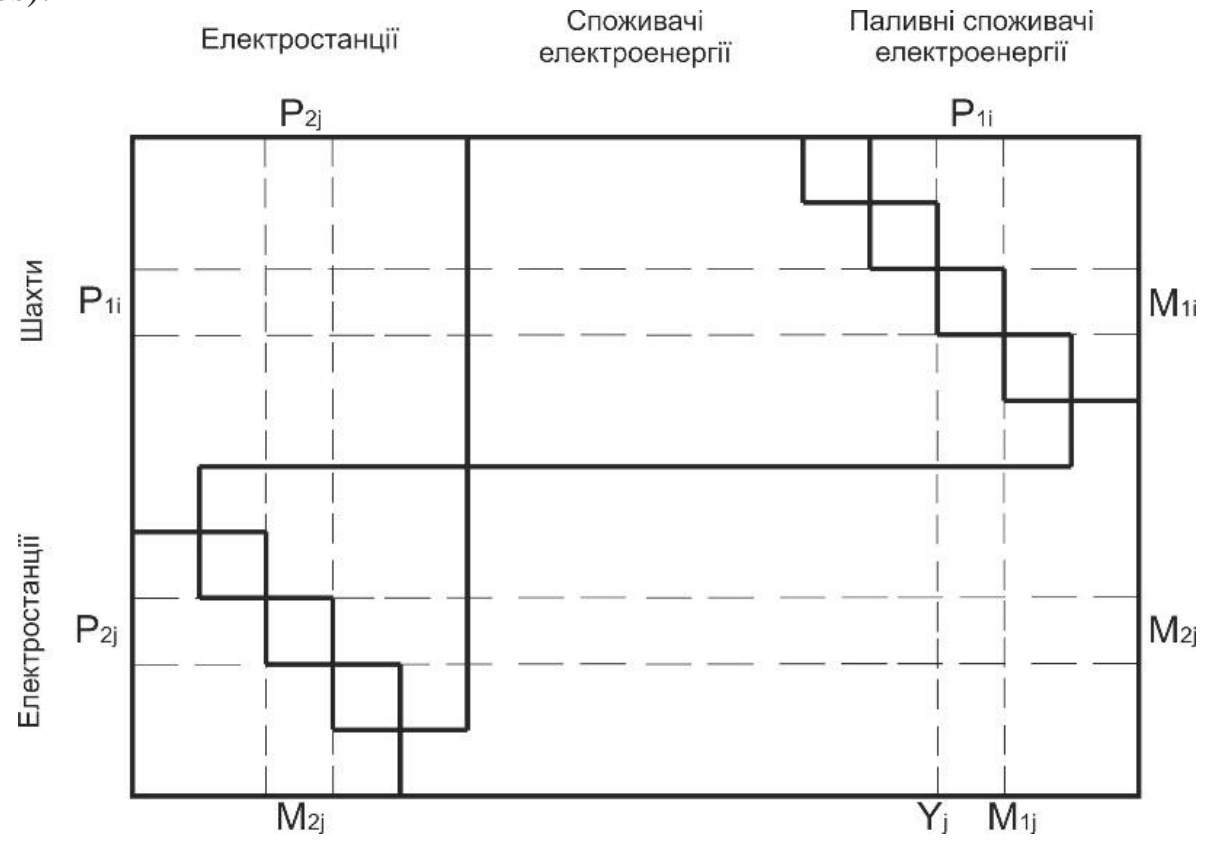

Електростанціï - Electric power stations

HIaxmu-Mines

Споживачі... - Consumers of electric energy

Паливні... - Fuel consumers of electric energy

Figure 1. Matrix of incidences "mines - electric power stations" [25]

Fig. 2 considers more complex case when the scheme includes not only mines but also processing plants, being provided with electric energy from those very electric power stations. The unused capacity of those plants should play a double role here: first, it provides correspondence between the amounts of raw coal being delivered to the plant; second, it represents real energy demand of the plant. 
As a rule such kind of distribution problems with additional limitations of $X_{i}=X_{2}$ type is solved by block methods.

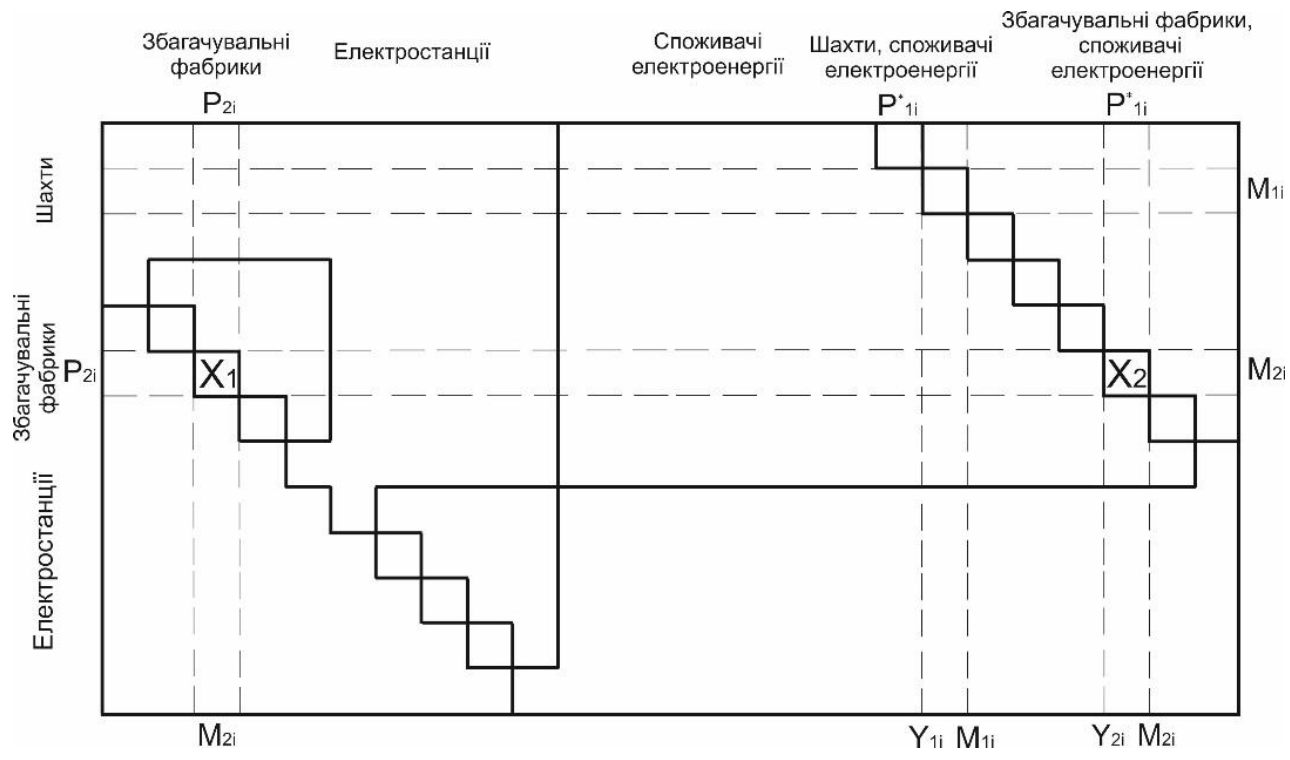

\section{Електростанцї - Electric power stations \\ Збагачувальні... - Processing plants \\ Haxmu-Mines}

Споживачi... - Consumers of electric energy

Шахти споживачі... - Mines, consumers of electric energy

Збагачувальні фабрики споживачі... - Processing plants, consumers of electric energy

Figure 2. Matrix of incidences "mines - processing plants - electric power stations" [25]

Identification of homogeneous groups of mines and determination of their costs for the increment of each production capacity ton, basing on the dependence of capital investment upon mining and geological factors, effecting them, is the simplest method of specifying the transformation indices (in this case, that is capacity increment depending on the level of capital assets). However, due to very complicated and joint influence of natural factors on capital investments while mine restructuring, it is practically impossible to perform quantitative evaluation of the effect of each of them in its pure form. In its turn, that prevents from forming homogeneous groups in terms of great variety of natural conditions of deposits and separate sites.

Analysis of the estimated cost of modernization of various-capacity mines within one and the same mining-geological site has made it possible to identify that corresponding investments can be divided conventionally into three parts: the ones changing directly proportionally to the mine capacity; the ones, experiencing their changes but with some delay from the capacity growth; and the ones being practically independent from the mine capacity. In this context, mine capacity affects the costs for improvement of general mine links. The indicated principles of modernization can be expressed by function $\phi_{i}(X)=\overline{1, n-1}$ that identifies maximum increment 
of mine capacity in terms of corresponding allocation of $X$ investment among $i$ mines. That is why a value of function $\varphi_{n}(X)$ is calculated only for value $X=S$ since the amount of investments allocated for all $n$ mines is equal to $S$.

We have studied the effect of the investment level on the capacity increment. Modelling of the output data was used as the basis to develop dependences of changes in productivity growth upon the attracted money for three state mines.

Table 1. Output data of dynamic modelling of the capacity increment of mines of State Enterprise State Coal Company

\begin{tabular}{|c|c|c|c|}
\hline \multirow{2}{*}{$\begin{array}{c}\text { Volume of } \\
\text { investments } X_{i} \\
\text { (UAH mln) }\end{array}$} & \multicolumn{3}{|c|}{$\begin{array}{c}\text { Increment of mine capacity } f\left(X_{i}\right) \text { depending on the } \\
\text { investment volume }\end{array}$} \\
\cline { 2 - 4 } & $\begin{array}{c}\text { Pivdennodonbaska } \\
\# 3\end{array}$ & $\begin{array}{c}\text { Pivdennodonbaska } \\
\# 1\end{array}$ & Kapitalna \\
\hline 50 & 86.8 & 1.6 & 24.2 \\
\hline 100 & 222.6 & 99.3 & 148.9 \\
\hline 150 & 302.1 & 156.5 & 221.9 \\
\hline 200 & 358.5 & 197.1 & 273.7 \\
\hline 250 & 402.2 & 228.5 & 313.9 \\
\hline 300 & 437.9 & 254.2 & 346.7 \\
\hline 350 & 468.2 & 276.0 & 374.4 \\
\hline 400 & 494.3 & 294.8 & 398.5 \\
\hline 450 & 517.4 & 311.4 & 419.7 \\
\hline 500 & 538.1 & 326.3 & 438.6 \\
\hline 550 & 556.7 & 339.7 & 455.8 \\
\hline 600 & 573.8 & 352.0 & 471.4 \\
\hline
\end{tabular}

We propose a simplified approach to the determination of the methods for investment redistribution depending on the level of economic reliability of mines. The problem is formulated as follows. To increase the volume of coal extraction by mines, capital investments are allocated in the amount of $S$ UAH mln. Use of $x_{i}$ UAH mln from the indicated investment by $i^{\text {th }}$ enterprise ensures increment of extraction being determined by the value of nonlinear function $f_{i}\left(X_{i}\right)$. It is required to identify the capital investment distribution among the mines that will ensure maximum increase in the output of finished coal products. Thus, the statements can be generalized from the viewpoint of modelling of trends in mine restructuring before the moment when diversification of mining regions will become a wellplanned and time-controlled process [26]. European practices have proved that hasty and unarticulated shutdown of closing mines cannot be considered as expedient due to the necessity to compensate the outgoing capacities with the imported energy carriers [27, 28].

Fig. 3 shows that each enterprise reacts to the investments depending on the state of mining economy, mining-geological conditions of occurrence, and technologies of deposit development. That is explained by the fact that there is a certain level of economic reliability for each enterprise being determined by the formula

$$
K_{e H t}=K_{m t} \times K_{e t}+K_{2 t},
$$


where $K_{\text {ent }}$ is index of economic reliability of a mine at the point of time or within a period $t ; K_{m t}$ is coefficient of technological reliability at the point of time $t ; K_{e t}$ is coefficient of economic level at the point of time $t ; K_{2 t}$ is index of the level of reserves left at the point of time $t$.

Technical and economic value of the index of economic reliability is in the fact that it is a complex evaluation of a mine in terms of the totality of its technical level and economic results of its functioning. That circumstance is of great practical importance. If we determine the economic reliability indices for regional mines, we can gain an objective situation of the mine fund. In addition, we will get a quantitative evaluation as only expert subjective or emotional estimations are often used. The available objective and complex evaluations help approach the solution of problems concerning priority of privatization of mines in the most substantiated way.

In particular, Kapitalna mine, which index of economic reliability is higher than the one of Pivdennodonbaska \#3 and Pivdennodonbaska \#1, ensures more efficiently the capacity increment. Basing on the regularities determined by us (Fig. 3) and depending on the level of economic reliability of mines, proceed to the solution of a problem concerning redistribution of UAH $600 \mathrm{mln}$ meant by the plans of development of State Enterprise State Coal Company for completing the reconstruction of Pivdennodonbaska \#1, Pivdennodonbaska \#3, and Kapitalna mines, i.e. to the determination of, first, conventionally optimal and, then, optimal investment distributions among the enterprises.

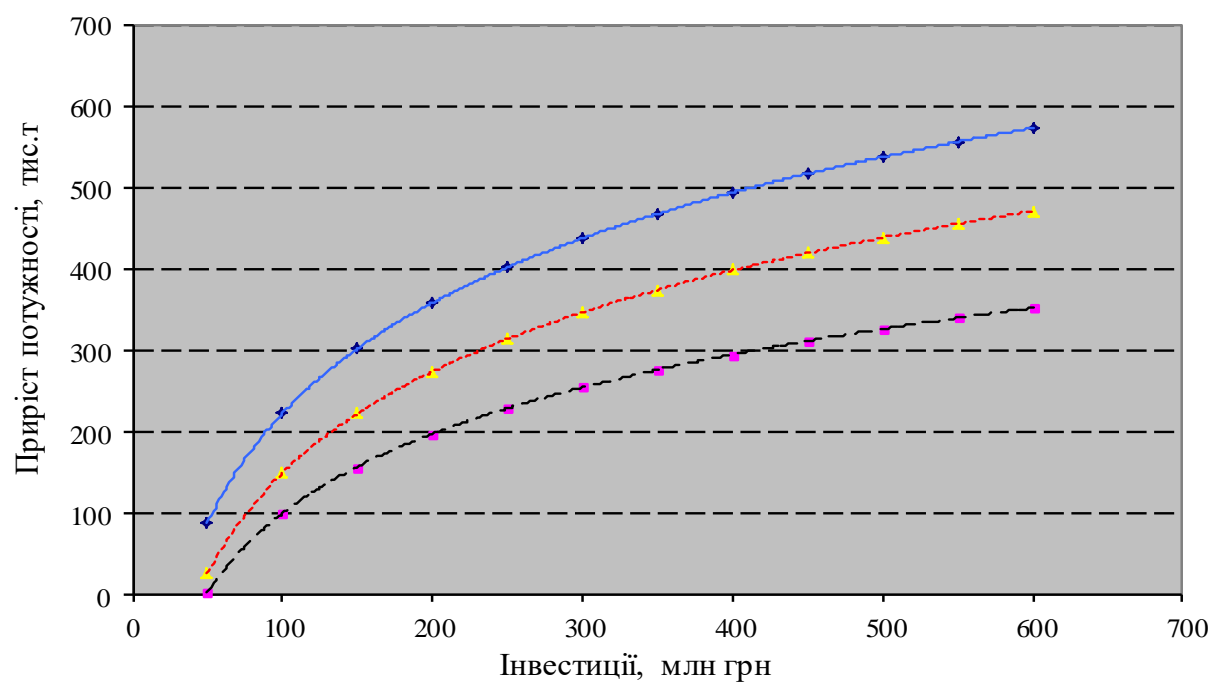

Capacity increment, thous. $t$

Investments, $\mathrm{UAH}$ mln

Figure 3. Capacity increment of the mines depending on the investment volumes

In terms of other variants of mine (mines) restructuring, the amount of capital investments for mining operations is determined basing on the calculated value of capital investments for mining operations in percentage of the mine capacity. The amount of capital investments for mining operations in percentage points grows 
along with the increasing mine capacity; possible risks of the environmental pollution should be also taken into consideration [29, 30, 31].

Consequently, solution of the problem of dynamic programming is expedient to start with the determination of optimal solution at the last $n^{\text {th }}$ step, i.e. for one mine [32]. To find that solution, one is obvious to have different assumptions as for how the next-to-last step can be completed and select the control providing maximum value of function $W_{n}\left(X^{(n-1)}, u_{n}\right)$. Such control selected in terms of certain assumptions, concerning the fact how the previous step is completed, is called conventionally optimal control. Thus, a principle of optimality requires determining conventionally optimal control at every step for each of the possible results of a previous step [33].

According to the determined algorithm, the first step involves consideration of possible investments for Pivdennodonbaska \#1 mine followed by the investment distribution between Pivdennodonbaska \#3 and Kapitalna mines. Move on to the calculation of values, using the corresponding data of previous calculations

$$
\varphi_{3}(X)=\max \left\{f_{3}\left(X_{3}\right)+\varphi_{2}\left(X-X_{3}\right)\right\} .
$$

The calculations prove that maximum capacity increment of the three mines can be at the level of 829.2 thous. $t$ in terms of investment distribution in the proportion of UAH $200 \mathrm{mln}$ for each mine during a six-year restructuring period. Table 2 represents the data concerning capacity increment of Kapitalna mine.

Table 2. Conventionally optimal volume of investments, in terms of Kapitalna mine

\begin{tabular}{|c|c|c|}
\hline $\begin{array}{c}\text { Amount of } \\
\text { investments } X_{\mathrm{i}}, \\
\text { (UAH ml.) }\end{array}$ & $\begin{array}{c}\text { Maximum increment } \\
\varphi_{2}(X) \text { of capacity, } \\
\text { thous. } \mathrm{t}\end{array}$ & $\begin{array}{c}\text { Conventionally optimal } \\
\text { volume of investment, in } \\
\text { terms of Kapitalna mine, } \\
\text { UAH mln }\end{array}$ \\
\hline 100 & 222.6 & 0 \\
\hline 200 & 358.5 & 0 \\
\hline 300 & 457.8 & 100 \\
\hline 400 & 555.5 & 200 \\
\hline 500 & 635.0 & 300 \\
\hline 600 & 692.2 & \\
\hline
\end{tabular}

The performed calculations of optimal values of the mines demonstrate potentials of the State Coal Company mines, which contain considerable reserves and have quite high level of economic reliability [34].

\section{DISCUSSION OF THE RESULTS}

Living standards of the population is the best index of the development of any region. This index is of complex nature. It is based on the level of monetary income of the population. However, that level is also nonuniform as it includes incomes from both production and non-production activity. Finally, they are reduced to the necessity of providing certain living standards for all members of society so that it 
would not be worse than in other regions. That is the idea, in terms of which we should talk about the uniform development of coal-mining regions. Those requirements are implemented in the organization of production of each region, which is a specific territorial economic complex. That provides maximum efficient development of productive forces aimed at complete satisfaction of national needs in finished coal products manufactured in the region and meeting the local needs to the fullest extent. Those are the key moments of planning the regional economies differing with their monoproducts - coal mining. During the studies, it has been identified that the level of ultimate production depends not only on the level of mechanization and organization of enterprise operations but also on the quality of the commercial deposit development. To solve a problem of effective allocation of funds between the groups of enterprises in terms of one legal entity, one should apply complex evaluation in terms of the "economic reliability" parameter, which takes into consideration quality of deposit development and level of concentration of operations. It has been determined that the most effective variant of transformation of coal-mining region's mines is as follows: compensation of possible reduction in output volumes, their required increment at the expense of additional load on the most efficient operating mines, and, as a rule, with less capital costs.

\section{CONCLUSIONS}

During the research, we have specified that a mechanism of evaluation concerning the decision-making on enterprise support means the overall estimation. The initial stage includes not only estimation of enterprise potential in terms of the available reserves, conditions of mine and production capacities, but also the involvement of an enterprise in social relations; possibility of diversification should also be considered for unprofitable enterprises. The following results have been obtained:

- currently, only one mine among the analyzed ones has good prospects; in this context, UAH 1.5 bln should be attracted for the development and implementation of design capacity for Kapitalna mine. This sum is higher than the volumes allocated by the state to support all the coal mines; consequently, the situation in Donetsk Region will not improve in the near future, conversely - a process of uncontrolled closure of production capacities will begin;

- increment of enterprise productivity depends on the level of attracted investments; however, the level of productivity implementation is different for each enterprise. That is explained not only by the level of currently attracted investments but also by the current state of an enterprise, being expressed by the degree of reserves preparation for extraction, length of mine workings, and level of work organization: all these can be evaluated by the universal parameter - economic reliability of an enterprise;

- mechanism of evaluation of coal enterprises means auditing of the production capacities, further modelling of the return from the level of involved resources as well as evaluation of economic reliability;

- paying attention to the fact that enterprises are involved not only in the process of coal extraction but also in the system of energy and metal production, 
further studies and conclusions concerning the expediency of enterprise functioning should be made, basing on the analysis of changes in the state of reserves during the transition from coal to metal or from coal to electric energy.

\section{СПИСОК ЛІТЕРАТУРИ}

1. Хорольський, А.О., \& Гріньов, В.Г., (2018). Проектування технологічних схем гірничого виробництва в умовах невизначеності. Физико-технические проблемы горного производства, (20), 132-146.

2. Гринев В.Г., \& Хорольский А.А. (2017). Обоснование параметров выбора комплектацій очисного оборудования с учетом области рациональной эксплуатации. $B e$ сти Донеикого горного института, 1(40), 139-144. http://doi.org/10.31474/1999981x-2017-1-139-144

3. Shapoval, V. \& Ashcheulova, A. (2012). Ecologic Component of Social Responsibility of Business (Experience of Poland and Ukraine). Common Europe: Ukraine and Poland under Conditions of Globalization and European Integration, Wydawnictwo Wyzszej Szkoły Bankowej, 183-193.

4. Salli, S., Mamaykin, O., \& Smolanov, S. (2013). Inner potential of technological networks of coal mines. Mining of Mineral Deposits, 243-246.

5. Mamaikin, O., Sotskov, V., Demchenko, Y., \& Prykhorchuk, O. (2018). Productive flows control in coal mines under the condition of diversification of production. In E3S Web of Conferences (Vol.60, p. 00008). EDP Sciences. http://doi.org/10.1051/e3sconf/20186000008

6. Salli, S., Pochepov, V., \& Mamaykin, O. (2014). Theoretical aspects of the potential technological schemes evaluation and their susceptibility to innovations. In Progressive Technologies of Coal, Coalbed Methane, and Ores Mining (pp. 491-496).

7. Mamaykin, O. R., Salli, S. V., Pochepov, V. M., \& Ashcheulova, O. M. (2015). Complex assessment of the recovery ratio of unprofitable mines. Mining of Mineral Deposits, 9(1), 135-139.

8. Гринев, В.Г., Хорольский, А.А. (2018). Оптимизация параметров эксплуатации очистного оборудования. Уголь Украины. (9), 37-42.

9. Сынков, В.Г., Гринев, В.Г., \& Хорольский, А.А. (2016). Оценка уровня взаимосвязи очистного оборудования в составе механизированного комплекса. Наукові праиі Донецького начіонального технічного університету. Серія: «Інформатика, кібернетика, обчислювальна техніка, (22), 124-132.

10. Hrinov, V. \& Khorolskyi, A. (2018). Improving the Process of Coal Extraction Based on the Parameter Optimization of Mining Equipment. In E3S Web of Conferences, Ukrainian School of Mining Engineering. (Vol. 60. p. 00017). EDP Sciences. http://doi.org/10.1051/e3sconf/20186000017

11. Амоша, А.И., \& Соломатина, Л.Н. (2017). Инновационное развитие промышленных предприятий в регионах: проблемы и перспективы, Экономика $У_{\kappa-}$ раины, (3), 20-34.

12. Гринев, В.Г., \& Хорольский, А.А. (2016). Обоснование рациональных параметров механизированной добычи угля на пластах пологого падения. Фізико-технічні проблеми гірничого виробнищтва, (18), 145-152.

13. Череватский, Д.Ю. (2018). Об экстернальной экономике угледобывающих гетерархий. Экономика промышленности, 4(84), 72-86.

14. Гринев, В.Г., Череповский, П.В., \& Деуленко, А.И. (2015). Инновационные перспективы эксплуатащии угольных пластов крутого падения. Днепр: Пороги. $180 \mathrm{c}$. 
15. Хорольский, А.А., \& Гринев, В.Г. (2018). Проектирование технологических схем очистного оборудования с использованием сетевых моделей: опыт и перспективы. Горная механика и машиностроение, (4), 12-21.

16. Nieć, M. (2009). Występowanie rud uranu i perspektywy ich poszukiwań w Polsce. Polityka energetyczna, (12), 435-451.

17. Zabierowski, J., Jaskowski, A., \& Cyrnek, C. (1981). Methods for scientific investigations in programming in the mining industry. Pr. Kom. Gorn. Geod. Gorn, (21), $39-47$.

18. Krzak, M. (2013). The Evaluation Of An Ore Deposit Development Prospect Through Application Of The" Games Against Nature" Approach. Asia-Pacific Journal of Operational Research. 30(06), 1350029.

19. Balusa, B.C., Singam, J. (2018). Underground mining method selection using WPM and PROMETHEE. Journal of the Institution of Engineers (India): Series D, 99(1), $165-171$.

20. Li, P. et al. (2011). Time series prediction of mining subsidence based on a SVM. Mining Science and Technology (China), 21(4), 55-562.

21. Beaulieu, M., \& Gamache, M. (2006). An enumeration algorithm for solving the fleet management problem in underground mines. Computers \& operations research, 33(6), 1606-1624.

22. Хорольський, А.О., Гріньов, В.Г., \& Мамайкін, О.Р. (2019). Інноваційні перспективи підземної експлуатації вугільних родовищ. Вісник Житомирського державного технологічного університету. Серія: Технічні науки, (83), 289-298. http://doi.org/10.26642/tn-2019-1(83)-289-298

23. Хорольський, А.О. (2017). Технологічні аспекти експлуатації вугільних родовищ. In Школа підземної розробки, (99-100).

24. Fomychov, V., Mamaikin, O., Demchenko, Y., Prykhorchuk, O., \& Jarosz, J. (2018). Analysis of the efficiency of geomechanical model of mine working based on computational and field studies. Mining of Mineral Deposits, 12(4), 46-55. http://doi.org/10.15407/mining12.04.046

25. Гріньов, В.Г., Хорольський, А.О., \& Мамайкін, О.Р. (2019). Декомпозиційний підхід при побудові систем генерації енергії у вуглепромислових регіонах. Bicmi Донецького гірничого інституту, (44), 116-126. http://doi.org/10.31474/1999-981x2019-1-116-126

26. Гріньов, В.Г., Хорольський, А.О., \& Мамайкін, О.Р. (2019). Оцінка стану та оптимізація параметрів технологічних схем вугільних шахт. Вісник Криворізького наиіонального університету, (48), 31-37. http://doi.org/10.31721/2306-5451-2019-148-31-37

27. Хорольський, А.О., Гріньов, В.Г., Мамайкін, О.Р. (2019). Оптимізація стійкості функціонування підсистем очисного вибою. Сучасні ресурсоенергозберігаючі технологіі гірничого виробнищтва, (23), 85-103. http://doi.org/10.30929/2074-1537.2019.1.85-103

28. Хорольський А.О., \& Гріньов В.Г. (2017). Системні принципи та оціночний критерій надійності при оптимізації технологічних схем вугільних родовищ. Вісник Житомирського державного технологічного університету. Серія: «Технічні науки», 80(2), 199-207. http://doi.org/10.26642/tn-2017-2(80)-225-233.

29. Khomenko, O., Kononenko, M., \& Myronova, I. (2017). Ecologic-and-technical aspects of iron-ore underground mining. Mining of mineral deposits, 11(2), 59-67. https://doi.org/10.15407/mining11.02.059

30. Khomenko, O., Kononenko, M., Myronova, I., \& Sudakov, A. (2018). Increasing ecological safety during underground mining of iron-ore deposits. 
Naukovyi Visnyk Natsionalnoho Hirnychoho Universytetu, (2), 29-38. http://dx.doi.org/10.29202/nvngu/2018-2/3

31. Khomenko, O., Kononenko, M., \& Myronova, I. (2013). Blasting works technology to decrease an emission of harmful matters into the mine atmosphere. Mining Of Mineral Deposits, 231-235. http://dx.doi.org/10.1201/b16354-43

32. Гріньов, В.Г., Хорольський, А.О., \& Каліущенко, О.П. (2019). Розроблення екологічних сценаріїв ефективного освоєння цінних родовищ корисних копалин. $\mathrm{Mi}$ неральні ресурси України, (2), 46-50.

33. Гріньов, В.Г., \& Хорольський, А.О. (2019). Оптимальне проектування параметрів гірничозбагачувальних підприємств для раціонального освоєння цінних родовищ України. Физико-технические проблемы горного производства, (21), 128-145. https://doi.org/10.37101/ftpgp21.01.008.

34. Petlovanyi, M.V., Lozynskyi, V.H., Saik, P.B., \& Sai, K.S. (2018). Modern experience of low-coal seams underground mining in Ukraine. International Journal of Mining Science and Technology, 28(6), 917-923. https://doi.org/10.1016/j.ijmst.2018.05.014

\section{REFERENCES}

1. Khorolskyi, A.O., \& Hrinov, V.H., (2018). Proektuvannia tekhnolohichnykh skhem hirnychoho vyrobnytstva v umovakh nevyznachenosti. Fyzyko-tekhnycheskye problemy hornoho proyzvodstva, (20), 132-146.

2. Hrynev V.H., \& Khorolskyi A.A. (2017). Obosnovanye parametrov vybora komplektatsii ochysnoho oborudovanyia s uchetom oblasty ratsyonalnoi ekspluatatsyy. Vesty Donetskoho hornoho instytuta, 1(40), 139-144. http://doi.org/10.31474/1999-981x2017-1-139-144

3. Shapoval, V. \& Ashcheulova, A. (2012). Ecologic Component of Social Responsibility of Business (Experience of Poland and Ukraine). Common Europe: Ukraine and Poland under Conditions of Globalization and European Integration, Wydawnictwo Wyzszej Szkoły Bankowej, 183-193.

4. Salli, S., Mamaykin, O., \& Smolanov, S. (2013). Inner potential of technological networks of coal mines. Mining of Mineral Deposits, 243-246.

5. Mamaikin, O., Sotskov, V., Demchenko, Y., \& Prykhorchuk, O. (2018). Productive flows control in coal mines under the condition of diversification of production. In E3S Web of Conferences (Vol.60, p. 00008). EDP Sciences. http://doi.org/10.1051/e3sconf/20186000008

6. Salli, S., Pochepov, V., \& Mamaykin, O. (2014). Theoretical aspects of the potential technological schemes evaluation and their susceptibility to innovations. In Progressive Technologies of Coal, Coalbed Methane, and Ores Mining (pp. 491-496).

7. Mamaykin, O. R., Salli, S. V., Pochepov, V. M., \& Ashcheulova, O. M. (2015). Complex assessment of the recovery ratio of unprofitable mines. Mining of Mineral Deposits, 9(1), 135-139.

8. Hrynev, V.H., Khorolskyi, A.A. (2018). Optymyzatsyia parametrov ekspluatatsyy ochystnoho oborudovanyia. Uhol Ukrayny. (9), 37-42.

9. Synkov, V.H., Hrynev, V.H., \& Khorolskyi, A.A. (2016). Otsenka urovnia vzaymosviazy ochystnoho oborudovanyia $\mathrm{v}$ sostave mekhanyzyrovannoho kompleksa. Naukovi pratsi Donetskoho natsionalnoho tekhnichnoho universytetu. Seriia: «Informatyka, kibernetyka, obchysliuvalna tekhnika, (22), 124-132.

10. Hrinov, V. \& Khorolskyi, A. (2018). Improving the Process of Coal Extraction Based on the Parameter Optimization of Mining Equipment. In E3S Web of Conferences, 
Ukrainian School of Mining Engineering. (Vol. 60. p. 00017). EDP Sciences. http://doi.org/10.1051/e3sconf/20186000017

11. Amosha A.I. \& Solomatina L.N. (2017). Innovacionnoe razvitie promyshlennyh predprijatij v regionah: problemy i perspektivy. Ekonomika Ukrainy, (3), 20-34.

12. Hrynev, V.H., \& Khorolskyi, A.A. (2016). Obosnovanye ratsyonalnykh parametrov mekhanyzyrovannoi dobychy uhlia na plastakh polohoho padenyia. Fizyko-tekhnichni problemy hirnychoho vyrobnytstva, (18), 145-152.

13. Cherevatskij D. Ju. (2018). Ob jeksternal'noj jekonomike ugledobyvajushhih geterarhii. Ekonomika promyshlennosti, 4(84), 72-86.

14. Grinev V.G., Cherepovskij P.V. \& Deulenko A.I. (2015). Innovacionnye perspektivy jekspluatacii ugol'nyh plastov krutogo padenija, «Porogi», $180 \mathrm{p}$.

15. Khorolskyi, A.A., \& Hrynev, V.H. (2018). Proektyrovanye tekhnolohycheskykh skhem ochystnoho oborudovanyia s yspolzovanyem setevykh modelei: opyt y perspektyvy. Hornaia mekhanyka y mashynostroenye, (4), 12-21.

16. Nieć, M. (2009). Występowanie rud uranu i perspektywy ich poszukiwań w Polsce. Polityka energetyczna, (12), 435-451.

17. Zabierowski, J., Jaskowski, A., \& Cyrnek, C. (1981). Methods for scientific investigations in programming in the mining industry. Pr. Kom. Gorn. Geod. Gorn, (21), $39-47$.

18. Krzak, M. (2013). The Evaluation Of An Ore Deposit Development Prospect Through Application Of The" Games Against Nature" Approach. Asia-Pacific Journal of Operational Research. 30(06), 1350029.

19. Balusa, B.C., Singam, J. (2018). Underground mining method selection using WPM and PROMETHEE. Journal of the Institution of Engineers (India): Series D, 99(1), $165-171$.

20. Li, P. et al. (2011). Time series prediction of mining subsidence based on a SVM. Mining Science and Technology (China). 21(4), 557-562.

21. Beaulieu, M., \& Gamache, M. (2006). An enumeration algorithm for solving the fleet management problem in underground mines. Computers \& operations research, 33(6), 1606-1624.

22. Khorolskyi A.O., Hrinov V.H., Mamaikin O.R. (2019). Innovatsiini perspektyvy pidzemnoi ekspluatatsii vuhilnykh rodovyshch. Visnyk Zhytomyrskoho derzhavnoho tekhnolohichnoho universytetu. Seriia: Tekhnichni nauky, (83), 289-298. https://doi.org/10.26642/tn-2019-1(83)-289-298

23. Khorolskyi, A. O. (2017). Tekhnologichni aspekti ekspluataciï vugil'nih rodovishch. In Shkola pidzemnoi rozrobki. Dnipro. pp. 99-100.

24. Fomychov, V., Mamaikin, O., Demchenko, Y., Prykhorchuk, O., \& Jarosz, J. (2018). Analysis of the efficiency of geomechanical model of mine working based on computational and field studies. Mining of Mineral Deposits, 12(4), 46-55. https://doi.org/10.15407/mining12.04.046

25. Hrinov, V.H., Khorolskyi, A.O., \& Mamaikin, O.R. (2019). Dekompozytsiinyi pidkhid pry pobudovi system heneratsii enerhii u vuhlepromyslovykh rehionakh. Visti Donetskoho hirnychoho instytutu, (44), 116-126. http://doi.org/10.31474/1999-981x2019-1-116-126

26. Hrinov, V.H., Khorolskyi, A.O., \& Mamaikin, O.R. (2019). Otsinka stanu ta optymizatsiia parametriv tekhnolohichnykh skhem vuhilnykh shakht. Visnyk Kryvorizkoho natsionalnoho universytetu, (48), 31-37. http://doi.org/10.31721/2306-5451-2019-1-4831-37

27. Khorolskyi, A.O., Hrinov, V.H., Mamaikin, O.R. (2019). Optymizatsiia stiikosti funktsionuvannia pidsystem ochysnoho vyboiu. Suchasni resursoenerhozberihaiuchi 
tekhnolohii hirnychoho vyrobnytstva, (23), 85-103. http://doi.org/10.30929/20741537.2019.1.85-103

28. Khorolskyi A.O., \& Hrinov V.H. (2017). Systemni pryntsypy ta otsinochnyi kryterii nadiinosti pry optymizatsii tekhnolohichnykh skhem vuhilnykh rodovyshch. Visnyk Zhytomyrskoho derzhavnoho tekhnolohichnoho universytetu. Seriia: Tekhnichni nauky, 80(2), 199-207. https://doi.org/10.26642/tn-2017-2(80)-225-233

29. Khomenko, O., Kononenko, M., \& Myronova, I. (2017). Ecologic-and-technical aspects of iron-ore underground mining. Mining of mineral deposits, 11(2), 59-67. https://doi.org/10.15407/mining11.02.059

30. Khomenko, O., Kononenko, M., Myronova, I., \& Sudakov, A. (2018). Increasing ecological safety during underground mining of iron-ore deposits. Naukovyi Visnyk Natsionalnoho Hirnychoho Universytetu, (2), 29-38. http://dx.doi.org/10.29202/nvngu/2018-2/3

31. Khomenko, O., Kononenko, M., \& Myronova, I. (2013). Blasting works technology to decrease an emission of harmful matters into the mine atmosphere. Mining Of Mineral Deposits, 231-235. http://dx.doi.org/10.1201/b16354-43

32. Grin'ov, V.G., Horol's'kyj, A.O., \& Kaliushhenko, O.P. (2019). Rozroblennja ekologichnyh scenarii'v efektyvnogo osvojennja cinnyh rodovyshh korysnyh kopalyn. Mineral'ni resursy Ukrai'ny, (2), 46-50.

33. Hrinov, V.H., \& Khorolskyi, A.O. (2019). Optymalne proektuvannia parametriv hirnychozbahachuvalnykh pidpryiemstv dlia ratsionalnoho osvoiennia tsinnykh rodovyshch Ukrainy. Fyzyko-tekhnycheskye problemy hornoho proyzvodstva, (21), 128145. https://doi.org/10.37101/ftpgp21.01.008.

34. Petlovanyi, M.V., Lozynskyi, V.H., Saik, P.B., \& Sai, K.S. (2018). Modern experience of low-coal seams underground mining in Ukraine. International Journal of Mining Science and Technology, 28(6), 917-923. https://doi.org/10.1016/j.ijmst.2018.05.014

\section{ABSTRACT (IN UKRAINIAN)}

Мета. Запропонувати новий підхід щодо механізму оцінки доцільності підтримки виробничих потужностей збиткових шахт Донецької та Дніпропетровської областей.

Методика. Для вирішення поставленої проблеми застосовано комплексний підхід, який включає оцінку інвестиційної привабливості підприємства, визначення виробничого потенціалу, визначення можливості переходу на беззбитковий режим. Процес планування шляхів збереження промислового потенціалу вуглепромислових регіонів може розглядатися як відображення багатовимірного простору (початкових і проектних величин) в одновимірний (суму інвестиційних коштів).

Результати. Встановлено, що на стадії побудови моделі управління процесами зниження збитковості шахти необхідно розглянути 8-10 факторних ознак, які можуть визначати формування економічного потенціалу з урахуванням особливостей залягання запасів, що залишилися та їх якості, як інтегральної оцінки потенціалу шахти в частині сприйняття інвестицій (державних та недержавних). Поставлена задача зводиться до відбору найменшого числа факторів, які б найбільш адекватно відображали внутрішній потенціал шахти 
у виразі економічної доданої вартості - як наслідок взаємодії факторів економічної діяльності вугільної шахти в конкретних гірничо-геологічних і технологічних умовах.

Наукова новизна полягає в тому, що в якості комплексної складової рівня стану збиткової шахти доцільно використати показник економічної надійності, який синтезує пропускну здатність ланок, економічний рівень технікоекономічних показників і обсяг запасів, що залишилися. Останні визначають залишковий термін служби шахти, фізичний зміст запропонованих показників неоднаковий, і саме ця обставина дозволяє при їх спільному використанні отримати більш повну, ніж при використанні якого-небудь одного показника, оцінку.

Практична значимість полягає у проведенні фактичної оцінки стану вугільних підприємств Донбасу та визначенні граничних показників беззбитковості, що дозволило сформувати рекомендації по залученню об' ємів фінансових ресурсів.

Ключові слова: вугільні шахти, вуглепромисловий регіон, беззбитковість, моделювання, диверсифікація, потенціал, запаси

\section{ABSTRACT (IN RUSSIAN)}

Цель. Предложить новый подход к распределению инвестиций в группе предприятий по добыче угля.

Методы. Для решения поставленной проблемы применен комплексный подход, включающий оценку инвестиционной привлекательности предприятия, определение производственного потенциала, определения возможности перехода на безубыточный режим. Процесс планирования путей сохранения промышленного потенциала углепромышленных регионов может рассматриваться как отражение многомерного пространства (начальных и проектных величин) в одномерный (сумму инвестиционных средств).

Результаты. Установлено, что на стадии построения модели управления процессами снижения убыточности шахты необходимо рассмотреть 8-10 факторных признаков, которые могут определять формирование экономического потенциала с учетом особенностей залегания оставшихся запасов и их качества, как интегральной оценки потенциала шахты в части восприятия инвестиций (государственных и негосударственных). Поставленная задача сводится к отбору наименьшего числа факторов, которые наиболее адекватно отражают внутренний потенциал шахты в выражении экономической добавленной стоимости - как следствие взаимодействия факторов экономической деятельности угольной шахты в конкретных горно-геологических и технологических условиях.

Научная новизна заключается в том, что в качестве комплексной составляющей уровня состояния убыточной шахты целесообразно использовать показатель экономической надежности, который синтезирует пропускную способность звеньев, экономический уровень технико-экономических показателей и объем оставшихся запасов. Последние определяют остаточный срок службы шахты, физический смысл предложенных показателей неодинаков, и 
именно это обстоятельство позволяет при их совместном использовании получить более полную, чем при использовании какого-либо одного показателя, оценку.

Практическая значимость заключается в проведении фактической оценки состояния угольных предприятий Донбасса и определении предельных показателей безубыточности, что позволило сформировать рекомендации по привлечению объемов финансовых ресурсов.

Ключевые слова: угольные шахты, углепромышленный регион, безубыточность, моделирование, диверсификация, потенциал, запасы

\section{ABOUT AUTHORS}

Asheulova Oleksandra, Candidate of Economical Science, Dnipro University of Technology, Associate Professor, 19 Yavornytskoho Avenue, Dnipro, Ukraine, 49005. E-mail: alex.mamaikin80@ gmail.com

Mamaikin Oleksandr, Candidate of Technical Science, Dnipro University of Technology, Associate Professor of the Mining Engineering and Education Department, 19 Yavornytskoho Avenue, Dnipro, Ukraine, 49005. E-mail: alex.mamaikin80@gmail.com

Pochepov Viktor, Candidate of Technical Science, Associated Professor, Dnipro University of Technology, Associate Professor of the Mining Engineering and Education Department, 19 Yavornytskoho Avenue, Dnipro, Ukraine, 49005. E-mail: alex.mamaikin80@gmail.com

Fomychova Ludmyla, PhD, Associated Professor, Dnipro University of Technology, Professor of the Higher Mathematics Department, 19 Yavornytskoho Ave., Dnipro, Ukraine, 49005. E-mail: alex.mamaikin80@ gmail.com

Lapko Viktor, Dnipro University of Technology, Senior Lecturer of the Mining Engineering and Education Department, 19 Yavornytskoho Avenue, Dnipro, Ukraine, 49005. E-mail: alex.mamaikin80@gmail.com 